\title{
Expectations and Results of Tax Reforms Implemented in Georgia
}

\section{Iza Bukia}

PhD Candidate in Economics Tbilisi State University, 0177, Georgia

DOI: 10.36348/SJEF.2019.v03i09.004 $\quad$ | Received: 07.09.2019| Accepted: 14.09.2019| Published: 20.09.2019

*Corresponding author: Iza Bukia

\section{Abstract}

Georgia is in the leading position in Europe with its tax policy, which is confirmed by many international ratings. According to the World Bank rating, Georgia ranks 6th in terms of ease of doing business. In terms of simplicity of paying taxes Georgia is also one of the distinguished ones. It is on the list of countries offering taxpayers a revised Tax Code and bylaws, also, for the simplicity of the relationship with the tax authority, most electronic services are offered [1]. Many tax reforms have been implemented to support entrepreneurs and expand their activities. This article provides a brief overview of the major tax reforms implemented since 2011 and research in entrepreneurs, which clearly reflects the expectations of the implemented reforms and the impact on the activities of the entrepreneurs.

Key words: Tax reform, Entrepreneurship, Economic policy, Tax policy, Georgia.

Copyright @ 2019: This is an open-access article distributed under the terms of the Creative Commons Attribution license which permits unrestricted use, distribution, and reproduction in any medium for non-commercial use (NonCommercial, or CC-BY-NC) provided the original author and source are credited.

JEL Classification: H2; H25; L2; L26; K34; E62.

\section{INTRODUCTION}

Georgia's tax policy is at the forefront of Europe, as evidenced by numerous international ratings. The main focus of Georgia's economic policy is sustainable economic development. To accomplish this The Socio-Economic Development Strategy of Georgia 2020 was developed, it is one of the most important documents and defines the main directions for economic development of the country and the ways of its implementation. The main directions of its economic policy include [2]. Rapid economic growth, implement economic policies that promote inclusive growth and the efficient use of natural resources. From the tax direction of the given strategy set goals such as: Improvement, refinement of the tax system and creating a stable tax environment; Improving the business environment for entrepreneurs; Simplifying tax administration; Shortening the limitation period; Liberalization/reduction of tax sanctions; Alleviation of economic crimes and in some cases cancellation etc. According to that, one of the country's priorities is the development of small and medium-sized businesses, Georgia's Small and Medium Entrepreneurship Development Strategy for 2016-2020 was developed, The goals and objectives of the following strategy include: "Increasing the competitiveness of SMEs in the local and international markets; Enhancing entrepreneurial skills and introducing a modern entrepreneurial culture; Supporting SMEs modernization and technological improvement" [3]. For SMEs, the strategy provides easier access to finance; Simplifying business closure; Improvement of insolvency procedure etc. In order to accomplish these goals, two agencies were created (LEPL Enterprise Georgia and Georgia's Innovation and Technology Agency) The purpose of which is to support SME development and support in financial, legal, business planning, innovation-based economy development, etc. It should be noted that the functions of both agencies include adapting to the requirements of the DCFTA.

In view of the above, various reforms have been implemented to support entrepreneurs, which should provide favorable conditions for their activities [4]. Target groups of tax reforms implemented were selected according to what category of entrepreneurs needed more support from the state.

\section{Implemented reforms and research on their impact on entrepreneurs}

Tax reforms have been implemented in Georgia for different categories of entrepreneurs. Consider the major reforms, what are the advantages and disadvantages of each and what have been the advantages that entrepreneurs have gained from the reforms. The research results are interesting in this regard (120 taxpayers interviewed), in order to study the impact of each reform on the activities of entrepreneurs. 
One of the target groups in the reforms implemented was entrepreneurs, who had relatively low gross income. Therefore, they were differentiated according to the above criteria and this category of taxpayers has fallen into special taxation regimes (micro, small and fixed taxpayer status). Micro, small and fixed taxpayer statuses were introduced into the Tax Code of Georgia in 2011. But the status of small business has undergone an additional change in 2018 . By granting these statuses, entrepreneurs are able to obtain the appropriate status based on the gross income earned per year. It is noteworthy that an entrepreneur with a micro-business status, whose upper limit of gross income is GEL 30,000, does not pay income tax. An entrepreneur with a small business status has been paying $1 \%$ or $3 \%$ since 2018 , depending on the amount of taxable gross income, with an upper limit of GEL 500,000 (Until 2018, the upper limit of gross income for an entrepreneur with small business status was GEL 100,000 , with a tax rate of $3 \%$ or $5 \%$ ). For a person with fixed taxpayer status, the rate is fixed, depending on the type of activity and varies from 1 GEL to 2000 GEL or 3\% of the income from taxable activities [5-9]. Based on the research, $93 \%$ of entrepreneurs with these statuses have a positive impact on their business, which unequivocally justifies the reform that has been adopted and gives great stimulus to entrepreneurs. $13 \%$ of entrepreneurs with positive impacts believe in the introduction of special taxation regimes in general, while an additional $13 \%$ consider raising the threshold of gross income for entrepreneurs with small business status and lowering the tax rate (See Diagram N1). Of the overall positive impact reforms, special taxation regimes are one of the important reforms.

When developing tax reform, it was very important to encourage entrepreneurs, who would reinvest. Reinvestment would be exempt from the tax, which is very important for the development of entrepreneurs. As a result, the profit tax reform, which came into force in 2017, has been one of the most extensive in recent years. This reform affected most of the activities, while for some categories (Commercial Bank, Credit Union, Insurance Organization, Microfinance Organization, Pawnshop, and the person who works in the systematic-electronic form of the totalizator in this part of the activity), the profit tax model remained in place until 2017 (It was defined as the difference between the taxable income of the taxpayer and considering the deductions by this Code). Naturally, this reform has many nuances, but the main difference between these two models is: That the beneficiaries of the new model of profit tax (the socalled Estonian model) do not tax on reinvested profit $[10,11]$. The purpose of this important legislative change is to encourage entrepreneurs to grow their businesses and not tax the money that will be used for reinvestment. This in turn will help to expand the business, which will also guarantee the creation of new jobs. This reform is intended for a long term [12].
However, it is worth noting that this reform has reduced the budget receipts in terms of profit tax and to some extent the budget was in danger of deficit (However, the excise tax on some products has been increased to balancing this). As for the results of the research on this reform, here is an interesting fact, that this reform falls into both positive and negative impact reforms, however, naturally there is a large percentage difference. It is noteworthy that the largest share (45\%) of the reforms with positive impact are named by the entrepreneurs (See Diagram N1). And of the negative impact reforms, $8 \%$ of entrepreneurs rate the reform as negative (See Diagram N2). But $64 \%$ of those who pay directly for the model report that reform has a significant positive impact on their business. It should be noted that the current tax rate $(15 \%)$ in Georgia is one of the most liberal in Europe.

Diagram N1 Positive impact tax reforms in terms of entrepreneurs

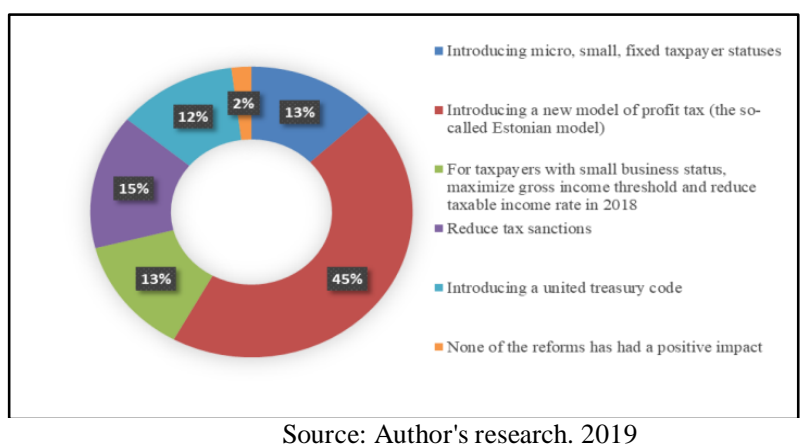

It should be noted that one of the areas of tax policy is the liberalization of tax sanctions. The Georgian Tax Code has been amended several times in recent years and this has affected various types of tax offenses, such as: Violation of the deadline for filing a tax return; Tax deduction in the tax return; Violation of the Rules of Use of the Cash Registry; Tax sanctions related to crossing the customs border of Georgia; In terms of tax audits etc. These sanctions have significantly reduced tax sanctions $[5,10,13]$. This will ensure that these sanctions do not place the burden on entrepreneurs. According to the survey, $15 \%$ of entrepreneurs think of positive impact reforms as reducing tax sanctions (See Diagram N1).

For entrepreneurs to interact with tax authorities and simplify their activities, reform has been implemented, where various Treasury codes were broken down by taxes and since 2016 it has become a United Treasury code [14]. Where absolutely all types of taxes are paid and for taxpayers are not broken down by type of tax. Of the positive impact reforms, $12 \%$ of entrepreneurs rated this reform as positive (See Diagram N1).

In order to simplify the activities for entrepreneurs, reform has also been developed, which 
includes automatic refund of surplus value (for entrepreneurs) of value added tax (VAT), which came into force in 2019 [15]. This reform is very large scale and also important for entrepreneurs. This serves to enable taxpayers to recover excess funds in a short period of time. Considering that the reform has already been adopted and has entered into force on 15 February this year, according to the survey, $53 \%$ of these taxpaying entrepreneurs did not use the service, while $25 \%$ favorably assessed the reform.

It is noteworthy that despite the positive impact reforms, negative impact reforms were also identified. The change in the excise tax has affected tobacco products, where the rate of excise tax has changed several times since 2015 , finally, the rate of increase by tobacco species ranges from $75 \%$ to $200 \%$ $[16,10,11,13]$. As a result, imports of tobacco products have declined, but the excise tax on tobacco mobilized in the budget has nevertheless increased [17]. This pressure is put on taxpayers and it naturally affects their business negatively, which is also evident in the survey, where $22 \%$ of entrepreneurs with negative impacts rate excise tax reform negatively (See Diagram N2). The effect of the increase in excise rates directly on the activity of the taxpayers concerned, the reform for $45 \%$ of entrepreneurs has a negative impact on their business. An important risk factor that may result in increased excise tax is that most of the activities (tobacco production / sale) move to the shadow economy and hence, reduce revenues in the budget.

In the context of value added tax (VAT) reform in 2017, advances have been made, that is, the amount of compensation received is taxable when determining the amount of a taxable transaction, The taxable transaction time shall be no later than that compensation for goods and / or services to be delivered or the moment of payment of a portion thereof [9]. This change may have been justified for the construction sector (If the entrepreneur is in the construction business, the proceeds from the sale of his apartments would be taxed only when the apartment is put into operation, but with this legislative change, the amounts taken by the building owner are considered to be advances and are taxable at the time of receipt of the funds, whether or not the apartment is in operation), however, since this has affected everyone regardless of the type of activity, therefore, this legislative change from tax reform to negative impact was assessed by $61 \%$ of entrepreneurs as negative (See Diagram N2). For those entrepreneurs who are VAT payers, 63\% of entrepreneurs think that this legislative change has had a negative impact on their business. In the case of this reform, the negative assessment of entrepreneurs has led to the determination of the taxation operation and its timing.
Diagram N2

Negative impact tax reforms in terms of entrepreneurs

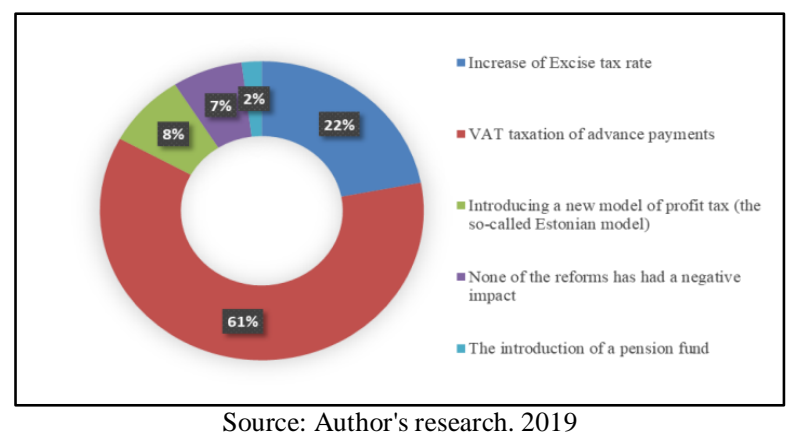

\section{CONCLUSIONS}

Based on research, recent reforms in Georgia are, in most cases, a positive impact and a step forward in supporting entrepreneurs. Whereas part of the reform was aimed at developing small businesses and encouraging them with various benefits, Also part of the reform was targeted at entrepreneurs interested in expanding their business, and consequently, a profit tax reform was implemented, that the funds used for reinvestment will not be taxed. Also, United Treasury Codes, where entrepreneurs can easily pay tax. Overpaid funds automatic return service, which is one of the important and simplified procedures for entrepreneurs. Liberalization of tax sanctions. All of the above-mentioned legislative changes are important areas of Georgia's tax policy that are being developed and promoted in the country's interest, and therefore, these reforms are a great challenge and at the same time encouraging entrepreneurs.

\section{REFERENCES}

1. WBG. (2019). Doing Business 2019

2. Socio-Economic Development Strategy of Georgia 2020

3. Georgia's SME Development Strategy for 20162020

4. Bukia, I. (2019). The influence of tax reforms implemented in Georgia for entrepreneurship development. Journal "Ecoforum", volume 8, issue N2, 584-586. Romania.

5. Georgian Tax Code. (2010). Tbilisi. (As of 2011)

6. Georgian Tax Code. (2010). Tbilisi. (As of 2018)

7. Bukia, I. (2019). Supporting Tax Policy for Small Business in Georgia, Journal "Economics and Business", N1, 122-126. Tbilisi.

8. Decree N415 of the Government of Georgia of December 29, 2010.

9. Decree N999 of the Minister of Finance of Georgia of December 31, 2010.

10. Georgian Tax Code. (2010). Tbilisi. (As of 2016)

11. Georgian Tax Code. (2010). Tbilisi. (As of 2017)

12. Bukia, I. (2018). The Estonian Model of Profit Tax - The Prospect of Economic Growth, Journal "Economisti", N3, 84-90. Tbilisi 
13. Georgian Tax Code. (2010). Tbilisi. (As of 2019)

14. Decree N407 of the Minister of Finance of Georgia of December 07, 2015.

15. Decree N42 of the Minister of Finance of Georgia of February 14, 2019.

16. Georgian Tax Code. (2010). Tbilisi. (As of 2015)
17. Chikvilade, M., Bukia, I. (2017). The Impact of Increased Tobacco Excise Rates on Import and Tax Revenues, II International Scientific Conference "Globalization Challenges in Economics and Business", 557-561. Tbilisi. 